\title{
Macroeconomic effects of unemployment benefits in small open economies: a stock-flow consistent approach*
}

\author{
Mikael Randrup Byrialsen** and Hamid Raza*** \\ MaMTEP, Department of Business and Management, Aalborg University, Denmark
}

\begin{abstract}
This paper attempts to analyse the macroeconomic effects of unemployment benefits in a small open economy. We adopt a stock-flow consistent (SFC) approach with an emphasis on the dynamics of the labour market. We numerically solve the model using a combination of estimation and calibration to generate statistics for our key variables, reflecting features of the Danish economy. We then analyse the effects of a fall in the unemployment compensation rate on the economy. The results indicate that a fall in the compensation rate at a macro level leads to a trade-off between a fall in aggregate demand and a rise in net exports. Due to this trade-off, the net effect of a fall in the compensation rate on the aggregate unemployment rate tends to be weak. Our analyses in this paper raise several questions on the existing views regarding unemployment benefits adopted by a large strand of the economic literature.
\end{abstract}

Keywords: stock-flow consistent models, labour market, unemployment benefits, macroeconomic outcomes, small open economies

JEL codes: $E 24, E 12, E 60, J 20, J 30$

\section{INTRODUCTION}

How do unemployment benefits (UBs) affect the labour market and macroeconomic outcomes? A high compensation rate on the one hand secures the unemployed against the loss of income, but on the other hand, it is widely believed to negatively affect the incentive for the unemployed to work. The effects of unemployment benefits on individual workers, the labour market, and the associated macroeconomic outcomes are still some of the least understood issues.

The dominant narrative - which argues that increasing UBs can increase unemployment can be theoretically explained from both the supply and demand perspectives. On the demand side, higher benefits lead to a higher demand for real wages from workers, which can result

* This paper was presented at the 4th Nordic Post Keynesian Conference, 20-21 April 2017 at Aalborg University, Denmark. The authors would like to thank Robert Smith and two anonymous readers, as well as the participants in the conference, for their comments on a previous version. All errors are exclusively ours.

** Email: randrup@business.aau.dk.

*** Email: raza@business.aau.dk.

Received 27 January 2017, accepted 7 December 2017 
in a lower level of demand for labour from firms (Diamond 1982; Shapiro/Stiglitz 1984). On the supply side, higher benefits imply that the unemployed sacrifice a smaller part of their future consumption, which can generate a disincentive effect in the labour market (Baily 1978; Hopenhayn/Nicolini 1997). However, the empirical evidence regarding the relationship between UBs and the level of unemployment is inconclusive. Some studies have found a positive correlation between UBs and unemployment (for example, Meyer 1990; Scarpetta 1996), while other studies have questioned the existence of any significant correlation (for example, Narendranathan/Stewart 1993; Howell/Rehm 2009; Howell/Azizoglu 2011b). In general, the relationship - if existing at all - has been found to be very weak in most cases (see Atkinson/Micklewright 1991 for a survey). In addition, quantifying the effects of UBs on macroeconomic outcomes is challenging, as described in Chodorow-Reich/Karabarbounis (2016), and the empirical mishandling of the issue is highlighted in several studies.

The literature on UBs has mostly focused on the effects related to consumption and worker behaviour towards the job market, at a micro level or by considering the labour market in isolation. A few recent studies, notably Krusell et al. (2010), Nakajima (2012), Mitman/Rabinovich (2015) and Kekre (2016) have addressed the macroeconomic effects of UBs, incorporating labour market frictions. These studies, while adopting the views put forward in classical search and matching theory, have reached very different conclusions. Consequently, the macroeconomic outcomes linked to unemployment benefits still remain unclear. Theoretically, the macroeconomic effects associated with UBs could greatly differ from those highlighted in micro studies and in models of the labour market. Unemployment benefits not only have direct effects on consumption at an individual level but also on wage setting, welfare and aggregate demand at a macro level. These macro effects in turn can have significant feedback effects on employment and the balance of payments of a small open economy.

The negative views regarding the effects of unemployment compensation on the economy have greatly influenced policy choices in Denmark. Over the last few decades, unemployment compensation rates ${ }^{1}$ have been reduced, as confirmed by Danish Economic Councils (DØRS). ${ }^{2}$ At the beginning of the 1980s, the rate at which the unemployed were compensated for the loss of income was set at 65 per cent of the average wage in the industry. The compensation rate declined to less than 50 per cent by 2015 (DØRS 2014; Cevea 2015). In particular, the recent decline in unemployment compensation is clearly linked to changes in labour market policy during this period.

This paper attempts to analyse the macroeconomic effects of unemployment benefits in a small open economy like Denmark. We adopt a stock-flow consistent (SFC) approach with an emphasis on the dynamics of the labour market. Our paper makes three important contributions. First, we develop a SFC model by integrating the dynamics of a labour market in a small open economy framework. To the best of our knowledge, this is the first paper addressing the issue of unemployment benefits at a macro level, using a SFC framework. Second, we critically analyse the proposals calling for a reduction in unemployment benefits as an appropriate policy to reduce unemployment. Third, our paper contributes to the ongoing debate on the possible effects of unemployment benefits at the level of unemployment, and macroeconomic outcomes. This paper raises several questions about the existing views on unemployment benefits adopted by a large strand of the economic literature.

1. Note that, while unemployment benefits have increased in level, the gap between benefits and salaries has widened over the last few years, that is, the compensation rates have fallen.

2. Danish Economic Councils referred to as De Økonomiske Råd Sekretariat (DØRS). 
The paper is organised as follows. Section 2 reviews relevant literature on the subject, highlighting some prominent contributions as well as discussing post-Keynesian views on the issue. Section 3 explains some core features of the Danish labour market along with its system of unemployment benefits. Section 4 proposes a SFC macroeconomic model of unemployment benefits. Section 5 numerically solves the model and introduces three main scenarios, followed by a discussion of the simulation results. Section 6 concludes the paper.

\section{LITERATURE REVIEW}

There is an extensive literature on the effects of unemployment benefits on the labour market. Most of the literature on the link between compensation rates and employment is based on the classical search theory (see Rogerson et al. 2005 for a survey). ${ }^{3}$ In general, a change in the unemployment benefits in these models has an effect on a worker's reservation wage and thereby whether a given job offer is accepted; a reduction in the unemployment benefits therefore leads to a reduction in the reservation wage, which can result in a shorter duration of unemployment (Rosholm 2006). While addressing the issue, a large strand of theoretical literature has focused on the trade-off between consumption-smoothing and the moral hazard effects of unemployment benefits (for example, Baily 1978; Flemming 1978; Shavell/Weiss 1979; Hopenhayn/Nicolini 1997; Chetty 2006). ${ }^{4}$

On the empirical front, several studies have tested these theories by investigating the correlation between incentives to work and job-search behaviour mainly using administrative data (see for example Katz/Meyer 1990 and Meyer 1990). A number of empirical studies in this area are reviewed by Andersen et al. (2015). Overall, the results in these studies indicate partial evidence that higher unemployment benefits are associated with lower traffic from unemployed to employed. The findings in some studies reject the existence of any significant correlation between UBs and the level of unemployment as described in Howell/Rehm (2009). On the contrary, the evidence in Howell/Rehm (2009) indicates that the causality could run in the opposite direction, that is, a change in unemployment may have the effect of changing UBs. The link between UBs and work incentives is also discussed in Howell/Azizoglu (2011a). Their results indicate that the link between benefits and work incentives may not be as strong as widely believed. ${ }^{5}$ The authors argue that

the evidence overwhelmingly shows that in the real world holding a job is typically highly valued independently of the income it generates, and if it is so, changes in UI [unemployment insurance] generosity may have nothing to do with changes in the disutility of work. (Ibid.)

Not only is there a question of causality between unemployment benefits and unemployment in empirical studies, but even the theoretical link between the two factors seems to lack coherence in the literature. The simplistic views regarding the relationship between unemployment benefits and unemployment, adopted by a large strand of the literature, are critically discussed in Atkinson/Micklewright (1991).

3. Earlier surveys on search theory in the labour markets can be found in Lippman/McCall (1976), Mortensen (1986) and Mortensen/Pissarides (1999).

4. The famous Baily-Chetty formula in public finance determines the optimum level of unemployment insurance (UI) by resolving this trade-off. Chetty (2008) derives a formula to determine the optimal level of UI by incorporating liquidity effects in the model.

5. In contrast to the standard utility assumption, Rätzel (2009) finds a positive relationship between work and happiness. 
In general, the critics of higher UBs have usually pointed to the adverse effects by highlighting the disincentive effect it might induce in the labour market. In contrast, the proponents of UBs have focused on the potential benefits by considering the consumption-smoothing effects (see for example Gruber 1997). Some authors have also focused on the welfare and macroeconomic effects of UBs. For example, Acemoglu/Shimer (2000) argued that in a less generous welfare system, workers tend to accept low productivity jobs to avoid unemployment, which in turn can have adverse effects on output and welfare. On the other hand, a more generous benefit system allows the workers to bear the risk of being unemployed and search for jobs with higher productivity, which can increase welfare and output.

In contrast to the mainstream theory, the post-Keynesian literature on the labour market clearly distinguishes the characteristics of the labour market from the goods market. ${ }^{6}$ At an aggregate level, the levels of employment and real wages are determined by effective demand and pricing policies (Davidson 1998; Arestis/Sawyer 2013: 311; Lavoie 2014: 277). This implies that an increase in aggregate demand will raise the level of economic activity, creating more jobs.

Focusing on the effects of unemployment benefits, post-Keynesian theory implies that an increase in unemployment benefits, if not reducing unemployment, may prevent a rise in unemployment via aggregate demand effects. However, the direct effects of unemployment benefits on the supply of labour are not obvious. Regarding the supply of labour, it has been argued that the decision to work along with conventional variables - such as wage rates - also depends on a number of factors, including norms, wages relative to other workers, consumption levels, and the standard of living. This implies that an increase in unemployment benefits may not force people to leave their jobs or stay unemployed for longer periods. In addition, there is no specific post-Keynesian view of the labour market at a micro level as highlighted by Lavoie (2014: 277), however the author argues that post-Keynesians in this regard may agree with the ideas of Institutionalist labour economists or industrial relations labour economists.

In general, post-Keynesians have proposed redistributive policies, favouring an increase in social expenditures - including unemployment benefits - which are important for income distribution. In particular, two main distributive policies - namely pro-labour and pro-capital - are described by Lavoie/Stockhammer (2013). The objective of a prolabour policy is to strengthen the welfare state, labour market institutions, labour unions, and the ability to engage in collective bargaining. An active pro-labour policy at an aggregate level may result in stable or increasing wage shares. An increase in unemployment benefits is therefore part of a pro-labour policy. A pro-capital policy on the other hand has the target of increasing labour market flexibility and weakening the bargaining power of the union, which may result in falling wage shares. ${ }^{8}$

The outcome of these policies, however, depends upon the growth regime of a country, as discussed in Lavoie/Stockhammer (2013), that is, whether an economy is wage-led or

6. The level of employment in basic neoclassical models is established in the labour market, and then enters the production function. The wage in the model is seen as a price of labour. This treatment of the labour market is comparable to the goods market.

7. Some of the economists of the 1950s mentioned by Lavoie (2014: 277) include John Dunlop, Clark Kerr and Richard Lester, whereas some of the recent ones include Lester Thurow, Michael Piore, Peter Doeringer, Barry Bluestone, David Howell and Frank Wilkinson.

8. Due to pro-capital policies, most advanced economies - including Denmark - have experienced a decline in wage shares over the last few decades, which is well documented in the post-Keynesian literature on financialization. 
profit-led plays a central role in this debate. ${ }^{9}$ A pro-capital policy in a profit-led growth regime will lead to a higher level of aggregate demand, which is likely to have positive effects on output and employment. On the other hand, a pro-capital policy in a wage-led growth regime will lead to a fall in aggregate demand, which is likely to have adverse effects on output and employment, unless such effects are offset by other factors, such as technological shocks, export growth or private debt, which can stimulate economic growth.

\section{A SYSTEM OF UNEMPLOYMENT BENEFITS}

We now turn to explaining some core features of the Danish labour market along with its system of unemployment benefits. The aim of the unemployment benefits system is to provide a security net by compensating workers in the event of a loss of income due to unemployment, that is, the system reduces the risks associated with unemployment. This generous system has been an important component of the well-known Flexicurity system. This system is famous for the combination of flexibility in the labour market, security for the single worker, and an active labour market policy (Bredgaard et al. 2011). This trinity is known as the golden triangle, which can be visually represented as shown in Figure 1.

From the perspective of the employer, this model is attractive because (i) it involves low employment protection, and (ii) the employers do not have to guarantee the income of workers if they decide to fire them. The labour unions accept this, despite the risk of being fired, because of the social security net, which provides high compensation for the loss of income (ibid.). The last corner of the triangle represents an active labour market policy, which is executed at a municipality level. This policy pursues the objective of putting unemployed individuals back to work, or to improve and upgrade their skills - for example, through education (Madsen 2011) - in order to prepare them for new employment opportunities. Together, the forces in this golden triangle have the purpose of increasing the dynamics of the labour market, resulting in low rates of unemployment.

Despite the success of the Flexicurity model, the security for workers - measured by both unemployment benefits (compensation rate) and the duration of benefits - has significantly declined over the last few decades. The average compensation rate, where the average unemployment benefit is compared to the average salary in the industry sector for the period 1980

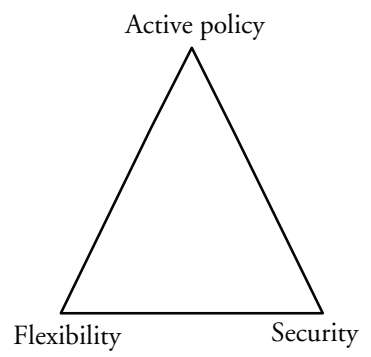

\section{Figure 1 The golden triangle}

9. An economy is wage-led if an increase in the profit share leads to a fall in the overall private aggregated demand. However, an economy can also be characterized as profit-led if an increase in the profit share is associated with an increase in aggregate demand. This issue has received considerable attention in recent post-Keynesian literature (see for example Onaran et al. 2011; Onaran/Galanis 2013; Stockhammer 2013). 


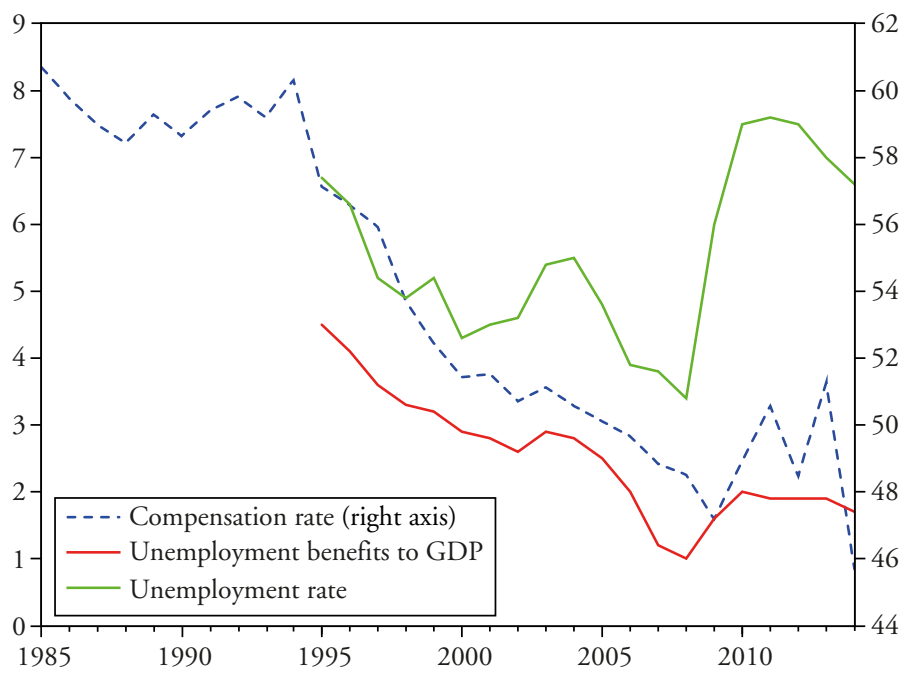

Figure 2 Unemployment rate and benefits in Denmark

to 2014, shows a significant decrease as can be seen in Figure 2. Figure 2 shows the comovement between the unemployment rate and expenditures on unemployment benefits as a percentage of GDP in Denmark. It can be seen that UB expenditures to GDP automatically increase (decrease) in response to a rise (fall) in unemployment rates.

The Danish parliament in 2010 implemented certain reforms targeting the system of unemployment benefits, which had two notable constituents: (i) the duration of UBs was reduced from 48 months to 24 months, and (ii) eligibility requirements for UBs were increased from 6 months to 12 months of full-time employment. The purpose of the reform was to increase employment and reduce government spending in order to improve the government's budget (DØRS 2014: 159).

In 2014, a commission was charged with the task of investigating how to make the existing system of unemployment benefits contemporary to the modern labour market. The recommendations from the labour market commission argued that the incentive to work must be increased by reducing unemployment benefits. A decline in the compensation rate, a tightening of the eligibility requirements, and a reduction in the duration of unemployment benefits - all of which were backed by the recommendations of the commission clearly indicate a tightening of the unemployment benefits system in Denmark. The security side of the golden triangle is therefore continuously deteriorating, which erodes the foundation of the Flexicurity model (Madsen 2011; 2015).

\section{MODEL}

In order to understand the macroeconomic effects linked to unemployment benefits in a small open economy, we develop a simple dynamic SFC model following the approach of Godley/Lavoie (2012). ${ }^{10}$ Although there are many ways to address this issue, a SFC model

10. Also known as the post-Keynesian SFC model. For a survey on the SFC approach to modelling, see Caverzasi/Godin (2014) and Nikiforos/Zezza (2017). 
incorporates many of the holistic modelling capabilities of other macroeconomic models. In addition, the SFC framework is the most appropriate to analyse the macroeconomic effects of UBs from a post-Keynesian perspective. ${ }^{11}$ Post-Keynesian views on the labour market can be coherently integrated with the goods and financial markets in a SFC framework, as will be discussed.

Since the core objective of the model is to address the issue of UBs, we integrate labour market dynamics in an open economy with limited financial activities. The economy is divided into five key sectors: households, firms, government, the central bank, and the rest of the world. The model will be explained in two key steps as follows. First, we will explain all the transactions taking place in the economy, alongside which we will also discuss the type of assets traded in the economy. Second, we will explain the structure of the model while focusing on the key equations regarding UBs in the economy.

\subsection{Transaction flow and balance sheet matrices}

The transaction flow matrix is presented in Table 1 (overleaf). The production in the economy takes place in the firms, which is represented as a standard expenditure approach to GDP in the national accounts. The firms hire workers (household) and pay them wages. They also pay taxes to the government, and trade with the rest of the world. Following the approach of Dos Santos/Zezza (2008), we assume firms have a fixed equity to capital ratio. They issue new equities whenever they decide to increase their capital. ${ }^{12}$ Firms make profits, a proportion of which are retained to finance investment expenditures and hold currency as an asset. ${ }^{13}$

Households at an aggregate level finance their consumption through wages, unemployment benefits and income on their asset holdings. Households hold three assets, namely government bills, domestic currency and equities. They also pay income taxes to the government.

The government expenditures consist of two main components: (i) government spending $(G)$, and (ii) unemployment benefits $(U B)$ transferred to the unemployed households. These expenditures are financed through taxes (received from households and firms) and bills. The central bank in the model acts as a clearing sector, that is, it fulfils the demand for local currency, and also holds any outstanding government bills in the economy. It also accumulates foreign currency reserves to ensure a fixed exchange rate.

Finally, the last column representing the interaction of the small economy with the rest of the world fulfils the balance of payments identities, that is, a surplus (deficit) on the current account equals a deficit (surplus) on the financial account.

The balance sheet matrix is presented in Table 2 (overleaf). A plus (+) sign indicates an asset, while a minus (-) sign represents a liability.

11. We prefer to use a SFC approach because it deviates from the approach based on the utility maximization problem of the workers, widely adopted in public finance and mainstream macroeconomics, that is, the decision to work in this framework negatively affects utility. As discussed earlier, post-Keynesian views on the labour market differ from those in public finance and mainstream macroeconomics.

12. The stock of capital does not grow over time in the steady state, therefore the change in equities (that is, the emission of new equities) is zero, and investment is financed by a proportion of retained profits. As a simplifying assumption, the firms issue equities irrespective of the cost, and any existing stock of equities is held by the household sector in the model. The rest of the portfolio choice of the households follows a standard portfolio allocation, as in Godley/Lavoie (2012). Moreover, there are no capital gains as the price of equities is fixed.

13. The holding of currency by the firms should be seen as an accounting identity from the perspective of the balance of payments, that is, the current account (trade) balance is equal to the financial (capital) account. 
342 European Journal of Economics and Economic Policies: Intervention, Vol. 15 No. 3

Table 1 Transaction flow matrix (TFM)

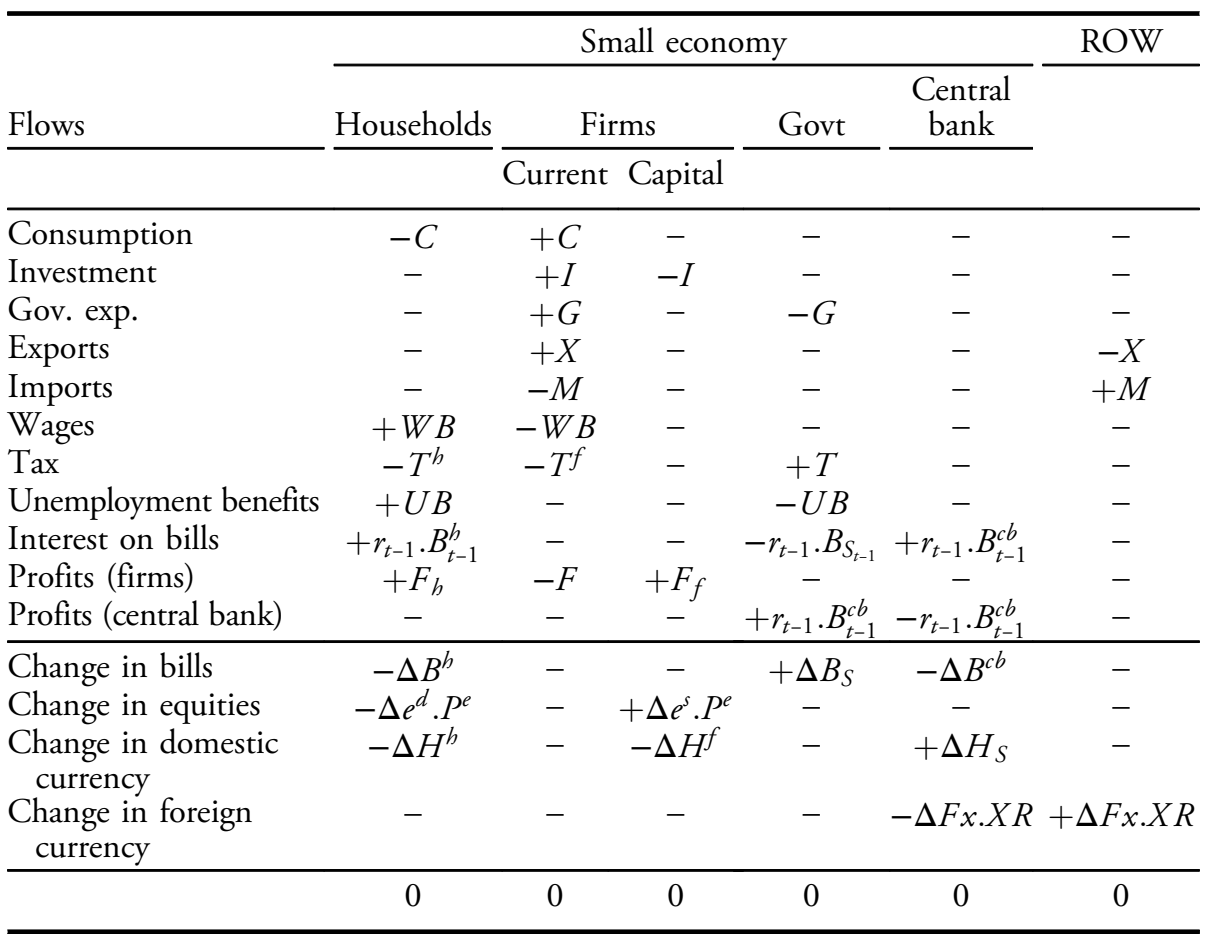

Table 2 Balance sheet matrix

\begin{tabular}{|c|c|c|c|c|c|c|}
\hline \multirow[b]{2}{*}{ Assets } & \multicolumn{4}{|c|}{ Small economy } & \multirow[t]{2}{*}{ ROW } & \multirow[b]{2}{*}{$\sum$} \\
\hline & Households & Firms & Govt & Central bank & & \\
\hline Bills & $+B^{h}$ & - & $-B_{S}$ & $+B^{c b}$ & - & 0 \\
\hline Equities & $+e^{s} \cdot P^{e}$ & $-e . P^{e}$ & - & - & - & 0 \\
\hline Domestic currency & $+H^{b}$ & $+H^{f}$ & - & $-H_{S}$ & - & 0 \\
\hline Foreign currency & - & - & - & $+F x . X R$ & $-F x . X R$ & 0 \\
\hline Fixed capital & - & $+K$ & - & - & - & $+K$ \\
\hline Net worth & $V_{h}$ & $V_{f}$ & $V_{g}$ & $V_{c b}$ & - & - \\
\hline
\end{tabular}

\subsection{Structure of the model}

The overall structure of the model is a combination of standard accounting identities and behavioural equations. ${ }^{14}$ The aggregate income of the household sector is an accounting identity, which can be determined as follows:

$$
Y D_{t}=W B_{t}+r_{t-1} \cdot B_{t-1}^{h}+F_{h}+U B-T_{t}^{h},
$$

14. The complete model along with the parameter values can be seen in Appendix 1 . 
where $Y D_{t}$ is the disposable income, $W B_{t}$ represents the wage bill, $r_{t}$ is the interest received by the household sector on its assets $B_{t}^{h}$ (government bill), $F_{h}$ represents the distributed profits, $U B$ is the unemployment benefits, and $T_{t}^{b}$ is the income tax paid by the household sector.

Following the standard post-Keynesian consumption function as generally used in SFC frameworks, ${ }^{15}$ the household sector consumes a portion of their disposable income and a fraction of their wealth. The consumption function can be represented as follows,

$$
c_{t}=\alpha_{1} \cdot y d_{t}+\alpha_{2} \cdot v_{t-1},
$$

where $c_{t}{ }^{16}$ represents aggregate real consumption, $\alpha_{1}$ is the parameter which represents the propensity to consume out of real disposable income $y d_{t}$, while $\alpha_{2}$ represents the propensity to consume out of real wealth $v_{t-1}$.

Production of goods takes place in the firms sector. The decision to invest is determined in a standard way, following the partial adjustment accelerator model as shown below:

$$
i_{t}=\gamma \cdot\left(k^{T}-k_{t-1}\right)+d a .
$$

Equation 3 simply states that real investment $i_{t}$ is determined by a partial adjustment $\gamma$ of the existing stock of capital $k_{t-1}$ towards a desired stock of capital $k^{T}$, plus a level of depreciation $D A$. The targeted capital (or desired stock of capital) is determined by a previous level of real sales (see equation (A11) in Appendix 1).

Prices $P_{t}^{s}$ are set as a mark-up $\phi$ over unit cost measured as the sum of wage bill $W B_{t}$ and imports $M_{t}$, divided by real sales of goods $s_{t}$.

$$
\begin{gathered}
P_{t}^{s}=(1+\phi) \cdot U C_{t} \\
U C_{t}=\left(W B_{t}+M_{t}\right) / s_{t}
\end{gathered}
$$

The level of employment is determined in the goods market, where firms will hire as many workers as needed to fulfil the demand for goods. ${ }^{17}$ The total cost of labour for the firms, as represented by the wage bill $W B_{t}$, can therefore be written as:

$$
W B_{t}=W_{t} \cdot N_{t},
$$

where $N_{t}$ represents the number of workers hired by the firms and $W_{t}$ represents nominal wages paid to the workers. The difference between the labour force $L f$ and the number of employed equals the number of unemployed individuals. The rate of unemployment can be expressed as follows:

$$
U R_{t}=1-\frac{N_{t}}{L f}
$$

Labour force $L f$ is determined by the labour participation rate of the total population, represented as follows:

$$
L f=\text { act.Pop }
$$

15. See Godley/Lavoie (2012) for a detailed discussion and motivation of several behavioural equations not discussed in this paper due to space and time.

16. Note that variables represented by lower-case letters represent real values whereas the ones written in capital letters represent nominal values.

17. In particular, the demand for labour is determined by real output over labour productivity as shown in equation (A36), that is, the firms produce a certain level of output by hiring workers with a given level of labour productivity, which is exogenously determined in our model. 
The participation rate $(a c t)$ in the model is determined by real wages and the employment rate. This setting for the Danish labour market is consistent with Statistics Denmark, ADAM (2003), as well as Godin (2014) in the SFC context. ${ }^{18}$ If real wages rise, the participation rate is expected to be higher, as individuals will search for jobs to increase their incomes, and become part of the labour force. If the rate of employment increases, the participation rate is expected to rise as more and more individuals enter the labour force. The equation can be represented as follows:

$$
\ln (a c t)=\Phi_{0}+\Phi_{1} \cdot \ln \left(w_{t}\right)+\Phi_{2} \cdot \ln \left(E R_{t-1}\right) .
$$

The level of unemployment benefits $(U B)$ paid to the unemployed households is represented as follows:

$$
U B_{t}=\xi . W_{t} \cdot U N_{t} \quad 0<\xi<1,
$$

where $\xi$ is the compensation rate in the model, which is exogenously determined by the government. For the unemployed, UBs represent present income, thus they prefer the compensation rate to be higher. In addition, the employed also have an interest in a high compensation rate in case of sudden redundancy.

Workers have some real wage aspirations, represented by the target real wage $w^{*}$, which is influenced by the compensation rate $(\xi)$, the rate of employment $(E R)$, and productivity $(A)$ as shown in equation (11) below: ${ }^{19}$

$$
\ln \left(w_{t}^{*}\right)=\beta_{0}+\beta_{1} \cdot \ln \left(A_{t}\right)+\beta_{2} \cdot \ln (\xi)+\beta_{3} \cdot \ln \left(E R_{t}\right) .
$$

This setting is similar to the wage equation in the benchmark model of Godley/Lavoie (2012) where the targeted real wage is a function of employment and productivity. However, our decision to incorporate the compensation rate in this equation is in line with standard models of 'wage setting', which argue that the compensation rate plays an important role in the determination of target real wages (see for example McDonald/Solow 1981; Shapiro/Stiglitz 1984; Sørensen/Whitta-Jacobsen 2005: 526-527). According to this argument, if the compensation rate goes up - for example, as a result of a more generous welfare system - workers will demand an increase in wages to maintain their incentive to work as against being unemployed.

Firms, in contrast to the higher demand for wages from workers, would prefer to pay lower wages in order to reduce costs. Therefore, a change in wages is the outcome of a bargain between the labour union and the firms, which can be represented as follows:

$$
\Delta W_{t}=\Omega_{0} \cdot\left(w_{t-1}^{*}-w_{t-1}\right) .
$$

The term $W_{t} / P_{t}^{d s}$ represents real wages, while $\Omega_{0}$ is the parameter of wage adjustment, which also represents the bargaining power of the union. ${ }^{20}$ Thus in the case of firms, the compensation rate has a dual effect in the model: a high compensation rate may stimulate demand at an aggregate level (see equations (1) and (2)), but at the same time a high rate may affect wage negotiations and thereby the unit cost of an individual firm (see equation (5)).

18. Annual Danish Aggregated Model (ADAM) is the official model used by Statistics Denmark and the Ministry of Finance in Denmark.

19. $\beta_{0}$ is the autonomous component of wages, while the rest of the parameters in the equation represent elasticities.

20. It should be highlighted that this parameter reflects the bargaining power of the union for an increase in wages only, that is, a union with stronger bargaining power will be faster in reinforcing higher wages, whereas it may be slower in reinforcing lower wages. 
In an open economy, a rise in the unit cost of firms due to an increase in wages will also affect their international competitiveness as can be shown in equations (13) and (14):

$$
\begin{aligned}
& \ln \left(m_{t}\right)=\mu_{0}-\mu_{1} \cdot \ln \left(\frac{P_{t-1}^{m}}{P_{t-1}^{y}}\right)+\mu_{2} \cdot \ln \left(y_{t}\right) \\
& \ln \left(x_{t}\right)=\epsilon_{0}-\epsilon_{1} \cdot \ln \left(\frac{P_{t-1}^{x}}{P_{t-1}^{y^{*}}}\right)+\epsilon_{2} \cdot \ln \left(y_{t}^{*}\right),
\end{aligned}
$$

where $\mu_{0}$ and $\epsilon_{0}$ represent autonomous components of the trade flows. $\mu_{1}$ and $\epsilon_{1}$ represent price elasticities of imports and exports, respectively. For example, if domestic prices $P_{t}^{y}$ increase relative to import prices $P_{t}^{m}$, the country will experience reduced competitiveness, resulting in higher imports $m_{t}$ and lower exports $x_{t}$. Similarly, if prices in the rest of the world $P_{t}^{y}$ increase relative to export prices of the domestic economy $P_{t}^{x}$, the competitiveness of the country will increase. The parameters $\mu_{2}$ and $\epsilon_{2}$ show the income elasticities of imports and exports, respectively. For example, if domestic income $y_{t}$ increases, imports will increase. Likewise, an increase in foreign income $y_{t}^{*}$ will increase exports. In our trade equations, we rely on a small economy assumption, that is, economic activity in the small economy has a negligible impact on the rest of the world. Hence, the prices $P^{y^{*}}$ and output $y^{*}$ abroad are exogenously determined in the model.

Equation (15) and (16) explain the prices of tradables from the perspective of our domestic economy.

$$
\begin{gathered}
\ln \left(P_{t}^{m}\right)=v_{m_{0}}+v_{m_{1}} \cdot \ln \left(P_{t}^{y^{*}}\right)+\left(1-v_{m_{1}}\right) \cdot \ln \left(P_{t}^{y}\right)+v_{m_{1}} \cdot \ln (x r) \\
\ln \left(P_{t}^{x}\right)=v_{x_{0}}+v_{x_{1}} \cdot \ln \left(P_{t}^{y^{*}}\right)+\left(1-v_{x_{1}}\right) \cdot \ln \left(P_{t}^{y}\right)+v_{x_{1}} \cdot \ln (x r) .
\end{gathered}
$$

Trade prices are affected by domestic prices, foreign prices and the exchange rate. The setting of the parameters implement some logical constraints on price movements of tradables. The model implies that, given a fixed exchange rate, a simultaneous increase in inflation of equal magnitude in the domestic economy and abroad will have the same effect on import and export prices, that is, the terms of trade will not be affected. This is ensured by setting the sum of the coefficients on domestic $\left(P_{t}^{y}\right)$ and foreign $\left(P_{t}^{y^{*}}\right)$ prices equal to unity. However, based on the well-established empirical fact, the parameter $\left(\nu_{m_{1}}\right)$ in the imports equation is greater than the parameter $\left(\nu_{x_{1}}\right)$ in the exports equation. This implies that, following a devaluation, the prices of both exports and imports will increase, but the terms of trade will fall due to a stronger increase in import prices, resulting in a positive effect on net exports. The above pricing equations, along with the specified constraints, have been used by a number of authors in the SFC framework for open economies, such as Lavoie/Daigle (2011), Mazier/Tiou-Tagba Aliti (2012) and GreenwoodNimmo (2013).

The government wants to reduce its expenditures, but, at the same time, it needs to fulfil its responsibility in the welfare state by paying UBs to unemployed households. The government in the model finances its expenses by issuing bills as follows:

$$
\Delta B_{S_{t}}=G_{t}+U B_{t}+r_{t-1} \cdot B_{S_{t-1}}-T_{t}-r_{t-1} \cdot B_{t-1}^{c b},
$$

where $B_{S_{t}}$ represents the total supply of bills, $G_{t}$ represents government consumption, $T_{t}$ represents total tax receipts, and $B_{t}^{c b}$ represents the interest payments by the central bank on government bill holdings. 
Before presenting the results of the model, we briefly discuss the process of calibration involved in solving the model with a focus on our key parameters. In setting the parameter values, our first priority is to rely on estimations reported for the Danish data by previous studies. However, in cases where estimations for the Danish data are not available, we rely on values tested to have generated stylised facts in previous SFC models.

\section{SIMULATIONS}

The parameters of the model are assigned values using a combination of estimation and calibration with the aim of generating statistics for our key variables, reflecting features of the Danish economy. Focusing on the key parameters, the compensation rate in our model is set to $\xi=0.55$, which is similar to the value mentioned in DØRS (2014) and Cevea (2015). The compensation rate affects wages indirectly through targeted wages, whereas the direct effect of compensation rates on the targeted wage is set to $\beta_{2}=0.1 .^{21}$ In the wage setting, the effect of employment rates on the targeted wage is set to $\beta_{3}=0.75$ in our model. Our decision to assign a value to $\beta_{3}$ in the wage-setting is consistent with the existing literature on wage curves, for which there is enough empirical evidence in several small economies. ${ }^{22}$ However, we will later show the response of the model when this parameter approaches the value of zero.

The labour participation rate is estimated using ordinary least squares (OLS) regression, where the coefficients $\left(\Phi_{1}\right)$ and $\left(\Phi_{2}\right)$ are estimated to be 0.05 and 0.23 , respectively. ${ }^{23}$ Our model replicates the participation rate in Denmark, which is roughly 0.75 , as reported by Statistics Denmark. The expenditures on UBs as a percentage of GDP is 2.5, which is almost equal to the mean of expenditures on UBs (as a percentage of GDP) during 1995-2015. The parameters in the consumption function $\alpha_{1}=$ 0.9 and $\alpha_{2}=0.1$ are set according to the results reported by Danmarks Nationalbank (2013). The price and income elasticities of the trade equations are based on the estimations for Denmark in ADAM (2012). The parameter on productivity - consistent with previous calibrated SFC models - is set to $\beta_{1}=1$. Other parameters appearing in the investment function and the price equations of the model are assigned values based on the analyses in previous SFC models, that is, these values fall within the range widely used in the SFC modelling tradition for open economies, such as Lavoie/Daigle (2011), Godley/Lavoie (2012), Mazier/Tiou-Tagba Aliti (2012) and Greenwood-Nimmo (2013).

We create a very open wage-led economy with a trade openness of 90 per cent of GDP, which is somewhat similar to the Danish economy where trade openness has fluctuated between 90 and 100 per cent of GDP since the mid 1990s. The economy in our model maintains a fixed exchange rate, as is the case in Denmark. We generate an unemployment rate of 5.6 per cent, which is very close to the mean of unemployment rates over the last two decades. Since the model is a large non-linear system of equations the model is simulated by using

21. While the transmission channel of compensation rates differs in the Annual Danish Aggregated Model (ADAM 2012), the effect of compensation on wages seems to be similar in magnitude to our setting.

22. See Blanchflower/Oswald (2005) for empirical evidence on the existence of the wage curve in more than 40 countries. Also, see Nijkamp/Poot (2005), for a meta-analysis on this relationship.

23. Based on the availability of data, the model is estimated using annual data for the period 1984-2015. 
Eviews, where a solution to the system of equations is found. ${ }^{24}$ However, this solution may not be a unique one since the existence of multiple solutions is a possibility. In case of multiple solutions, the chosen initial values restrict the achieved solution to be a local solution within a chosen domain ${ }^{25}$ - a solution procedure that this study has in common with several other non-linear SFC models, such as Lavoie/Daigle (2011) and Greenwood-Nimmo (2013). Consistent with the standard practice in numerical SFC models, we first simulate the model to achieve a baseline steady state. We create three scenarios in the model as follows: (i) reduce the compensation rate, (ii) introduce downward real wage rigidity, and (iii) decrease the effect of employment on targeted wages.

\subsection{The effects of a lower compensation rate}

We now turn to addressing the core question raised in this paper: what are the macroeconomic effects of unemployment benefits in a small open economy? To address this question, we generate a scenario in the model by reducing the compensation rate $\xi$ from 0.55 to 0.5 .

Focusing on the macroeconomic effects, a reduction in the compensation rate affects the economy in two ways. First, a decrease in the compensation rate directly affects the income of unemployed individuals, which can result in a demand compression. Second, reducing the compensation rate puts downward pressure on wages, which will increase international competitiveness via the price channel, and the economy can experience export-led growth. The latter argument is also used as a justification for a lower compensation rate.

Figure 3 (overleaf) shows unemployment benefits as a percentage of GDP; ${ }^{26}$ it can be seen that a fall in the compensation rate leads to lower expenditures on UBs, as expected. Figure 4 (overleaf) shows the effect of a lower compensation rate on the rate of unemployment in our model. In the short run, a negative shock to the compensation rate initially increases the unemployment rate, as the income of the unemployed labour force falls, resulting in a demand compression. The unemployment rate then falls as the effects of increased competitiveness - as a result of lower wages - dominate the effect of a demand compression. The effects of a lower compensation rate on domestic demand and GDP are shown in Figure 5 (overleaf). A decline in the terms of trade (or an increase in competitiveness) generates a current account surplus as shown in Figure 6 (overleaf).

24. The system of equations can be divided into three blocks of equations, where blocks 1 and 3 could be solved recursively, while block 2 must be solved simultaneously. To solve the system of equations in block 2 the Newton method is used. The Newton method is an iteration algorithm, where a linear approximation around a specific set of values for the vectors of endogenous and exogenous variables is used to build an iteration process. An initial guess to solve the system begins the iteration process, which stops when the changes in values of the vector with endogenous variables are below a pre-specified level of tolerance, which in this simulation is set to 1e-8. For further details on non-linear solutions in Eviews, see the users manual: http://www.eviews.com/help/helpintro. html\#page/content $\% 2$ Fpreface.html $\% 23$.

25. The values of exogenous variables can be found in Appendix 1. The model code is available upon request.

26. Note that the $y$ axis on GDP and domestic demand represents real values, obtained from the simulated model. All graphs, with the exception of the unemployment rate, are represented as a percentage of GDP. The unemployment rate is expressed as a proportion of the labour force as defined in equation (7). 


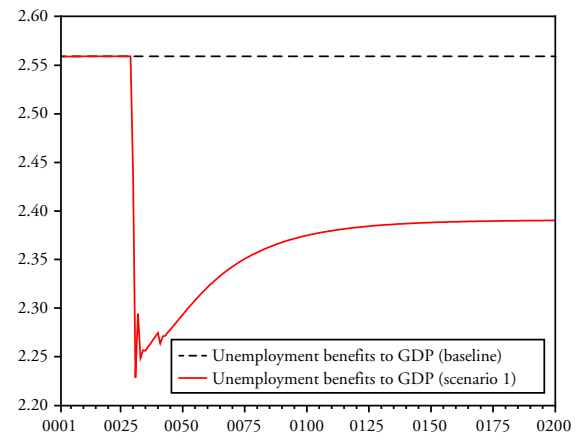

Figure 3 Unemployment benefits to GDP

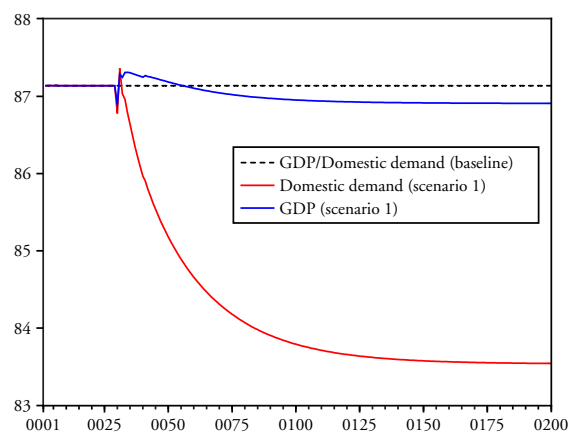

Figure 5 GDP (and domestic demand)

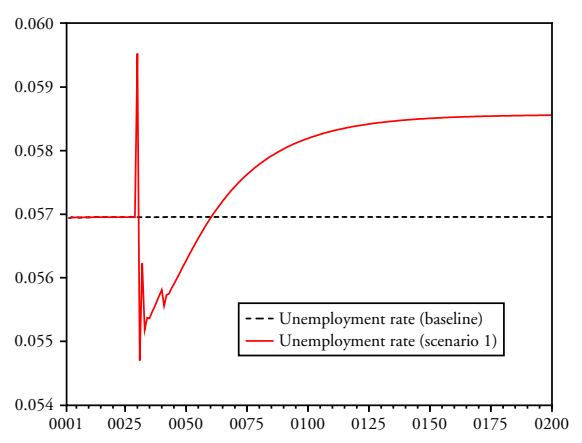

Figure 4 Unemployment rate

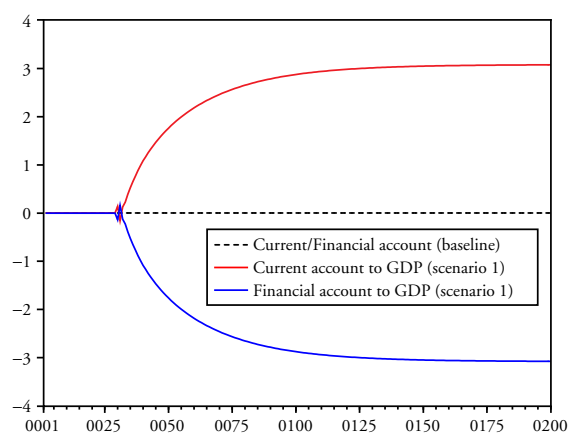

Figure 6 Current and financial accounts

In the long run, the model stabilises at an unemployment rate slightly higher than the baseline scenario. This adjustment in the long run is due to a decline in competitiveness over time, stemming from the wage-curve effect, that is, a reduction in the unemployment rate increases the targeted wages in the model.

\subsection{Introducing downward real wage resistance}

In our baseline model, the effect of the compensation rate on real wages is symmetric, that is, the response of real wages to both negative and positive shocks is similar in magnitude. Thus, we did not restrict a negative compensation rate shock to have a significant downward pressure on real wages. However, there is now ample empirical evidence for the existence of downward wage rigidity, especially in advanced countries with strong labour unions. ${ }^{27}$ Labour union resistance to a decline in wages in the bargaining process has now become an essential component of macroeconomic models. ${ }^{28}$ From a behavioural perspective, as described by Kahneman/Tversky (1979), individuals are more resistant to losses than they are attracted to gains of similar magnitude.

27. See for example Agell/Lundborg (2003), Christofides/Li (2005) and Holden/Wulfsberg (2009).

28. See for example Hall (2005) and Blanchard/Galí (2007). 
The above discussion leads to another key question: what are the effects of unemployment benefits in a small open economy when there is strong resistance to reductions in real wages? In order to address this issue, we adjust our model by decreasing the effect of the compensation rate on targeted wages; we reduce the value of $\beta_{2}$ from 0.1 to 0.05 . It is important to stress that after reducing the effects of the compensation rate on targeted real wages, we still generate the same baseline scenario as previously discussed. ${ }^{29}$ After achieving the baseline scenario, we introduce a compensation rate shock by reducing the value of $\xi$ from 0.55 to 0.50 , as was done in scenario 1 discussed above.

Looking at Figures 7, 8, 9 and 10, the results are not surprising. A decrease in the compensation rate in an environment of downward real wage rigidity leads to a higher unemployment rate as compared to the baseline scenario. In the short run, the unemployment rate immediately increases due to a fall in aggregate demand. The unemployment rate then drops due to an increase in the level of competitiveness. However, the fall in the unemployment rate is much lower than in scenario 1 . The difference between scenario 1 and scenario 2 is straightforward: a reduction in the compensation rate now has a lower impact on the relative prices (or the level of competitiveness), as targeted wages are resistant to falls. The diminished effect of competitiveness in the economy can be

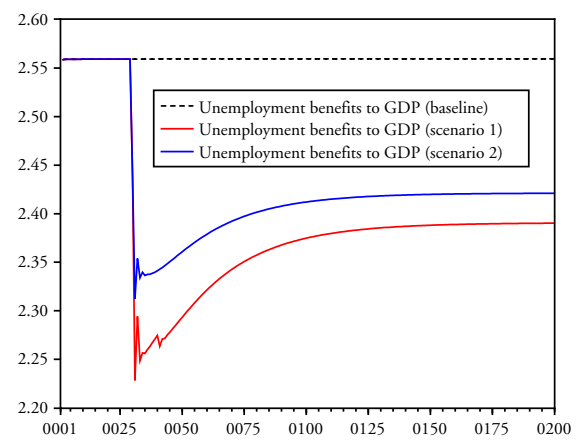

Figure 7 Unemployment benefits to GDP

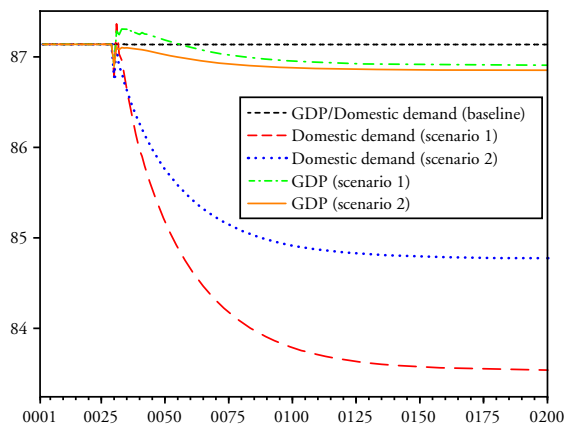

Figure 9 GDP (and domestic demand)

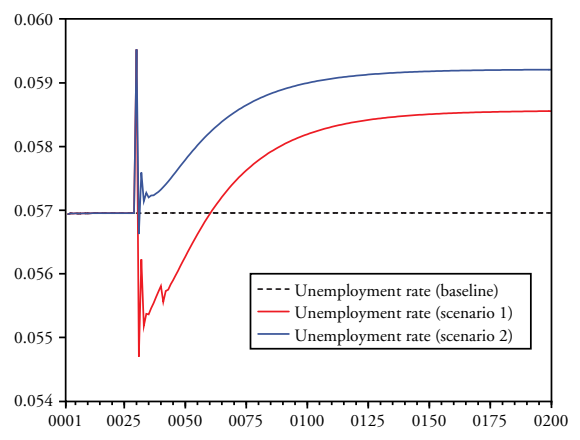

Figure 8 Unemployment rate

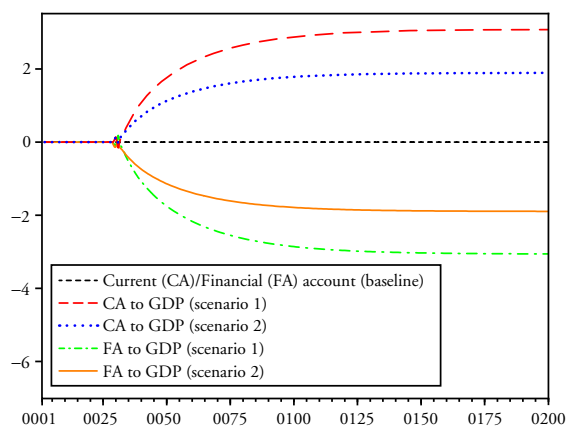

Figure 10 Current and financial accounts

29. We do this by readjusting the autonomous component $\left(\beta_{0}\right)$ in equation (11). The purpose of maintaining the same baseline scenario is to consistently compare different scenarios. 
seen in a relatively lower current account surplus as compared to scenario 1 . In the long run, the model stabilises, reaching an unemployment rate higher than in the case of scenario 1 , where real wages were relatively more flexible. The adjustment mechanism of the model towards a new steady state remains the same as in scenario 1 .

\subsection{Decreasing the effect of employment on wages}

In the baseline model, a change in the rate of unemployment affects the targeted real wages. This, as discussed earlier, can be seen as an argument for the existence of a wage Phillips curve. However, in a number of studies, including Hein/Stockhammer (2011), Godley/ Lavoie (2012) and Lavoie (2014), a Phillips curve with a horizontal section is proposed. In these studies, it has been argued that fluctuations in the employment rate within certain bands (that is, smaller changes in the employment rate) do not affect the targeted real wages. We introduce this feature in our model by lowering the elasticity of the employment rate $\left(\beta_{3}\right)$ to the targeted real wage. In this scenario, the effects of a change in the compensation rate $\xi$ are analysed within an environment of a relatively flat Phillips curve. As in Section 5.2, this is done by first creating the baseline scenario (after changing the value of $\beta_{3}$ from 0.75 to 0.5 ) and thereafter reducing the value of $\xi$ from 0.55 to 0.5 .

The results of this simulation for relevant macroeconomic variables are reported in Figures 11, 12, 13 and 14 . The results look quite similar to the results from the first

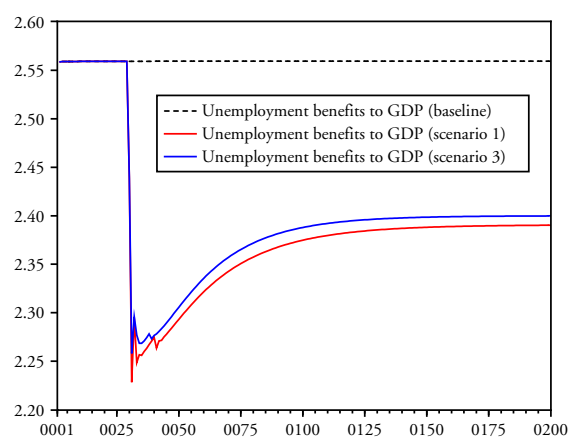

Figure 11 Unemployment benefits to GDP

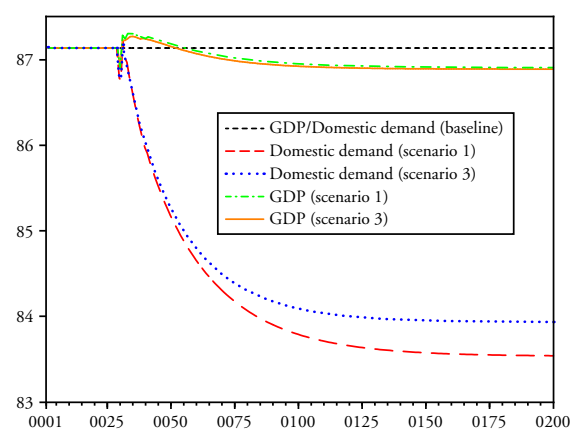

Figure 13 GDP (and domestic demand)

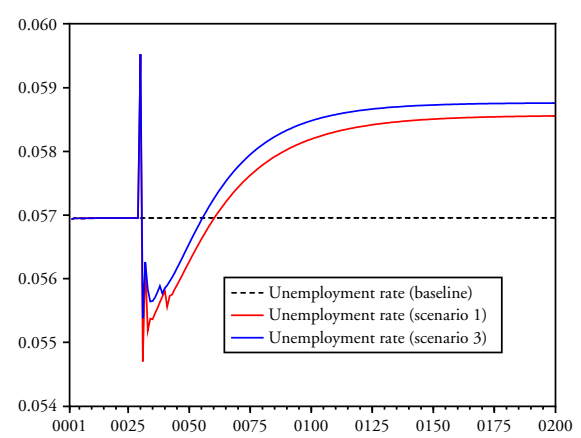

Figure 12 Unemployment rate

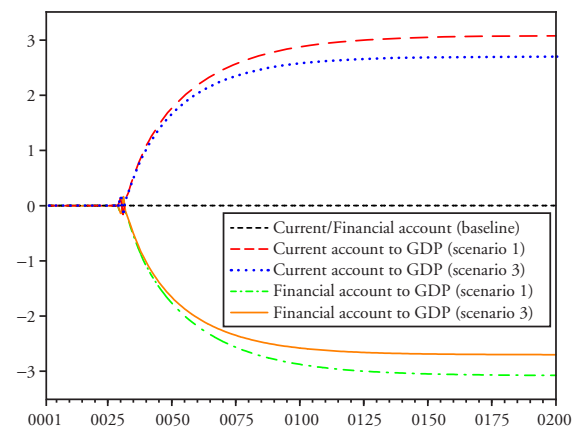

Figure 14 Current and financial accounts 
scenario. In the short run, the reduction in the compensation rate lowers the income of the households, and thereby lowers the domestic demand. This fall in aggregate demand results in an increase in the rate of unemployment.

In the medium term, however, the effect of increased competitiveness starts to dominate the contraction of domestic demand. This increases competitiveness as can be seen by the positive current account balance shown in Figure 14. The dynamics seem to be identical to scenario 1, but with some important distinctions: the effects of a lower compensation rate on the unemployment rate are slightly stronger in the long run as compared to scenario 1 . This is due to a stronger fall in domestic demand and a relatively weak response of the current account. In the current scenario, the effect of a change in the employment rate on real wages is set to be weaker. Therefore when the employment rate falls as a result of a fall in domestic demand, real wages do not fall as much as in scenario 1, resulting in a relatively weak effect on the level of competitiveness.

\subsection{Robustness}

We perform several robustness tests by changing the values of parameters. After changing the parameters, we introduce the same three scenarios - as discussed earlier - and simulate the model. The new results are compared with those of the main model, referred to as the 'benchmark model'.

Our first experiment involves changing the key parameters in the trade equations. Overall, the parameter values in the trade equations are increased, which implies that the tradables are more sensitive to price movements and income variations. ${ }^{30} \mathrm{We}$ assign values to these parameters based on the empirical results reported for sensitive goods, that is, the goods with the highest elasticities in the trade sector. In particular, $\epsilon_{2}$ in the export equation is increased from 0.62 to 1 , which is close to the elasticity reported for tourism and manufactured goods in the Danish export sector. The price elasticity of exports $\epsilon_{1}$ is increased from 1.6 to 2 , which is the elasticity of manufactured goods. At the same time, the price elasticity of imports $\mu_{1}$ is increased from 0.4 to 1 , which is close to the elasticity of primary goods. The income elasticity of imports $\mu_{2}$ is increased from 1.11 to 1.47 , which is close to the elasticity reported for manufactured goods.

Given that the demand for tradables is sensitive to price and income variations, a fall in the compensation rate would result in lower unemployment in the short run as compared to the benchmark model. This is due to the strong effect of relative prices on net exports, increasing output and reducing the unemployment rate as shown in Figures 15 and 16 (overleaf), respectively. However, the unemployment rate increases in the long run due to stronger feedback effects of income on imports. In the long run, the results for the three scenarios are quite similar across the two models.

In addition, we perform a separate experiment in which we perform sensitivity checks on the equations involving the determinants of prices of imports and exports. In particular, we make the import prices more responsive to the developments in foreign prices and less responsive to domestic prices by increasing the value of $v_{m_{1}}$ from 0.7 to 0.8 . At the same time, we make export prices less sensitive to foreign prices and more sensitive to domestic prices by reducing the value of $\nu_{x_{1}}$ from 0.4 to 0.2 . These changes lead to a negligible impact on the overall model, as can be seen in Figure 17 and 18 (overleaf).

30. Note that the parameters involved in this experiment are changed simultaneously. 


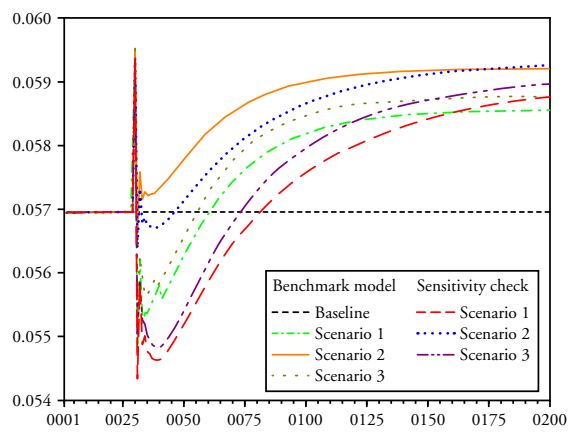

Figure 15 Unemployment rate

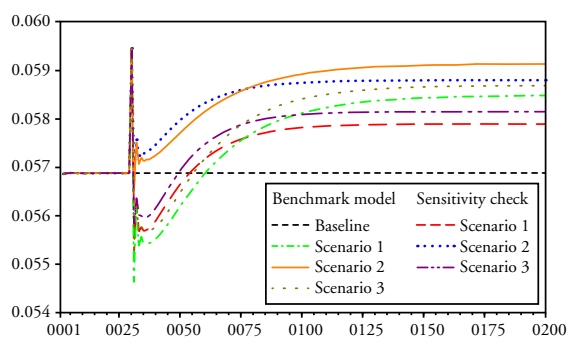

Figure 17 Unemployment rate

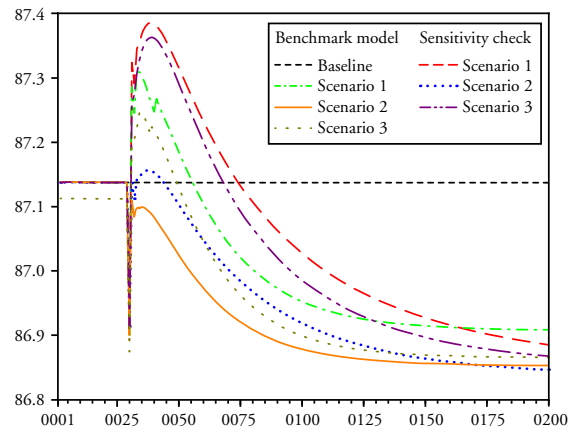

Figure 16 GDP

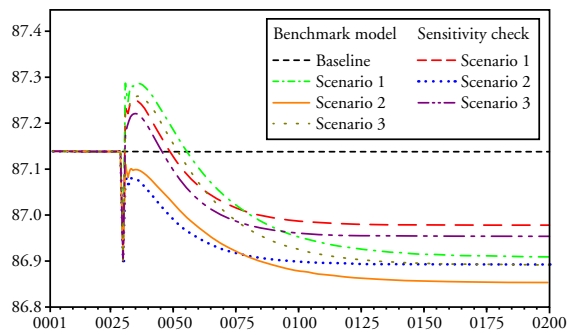

Figure 18 GDP

Second, we test the sensitivity of the model by changing a strategic parameter in the wage-setting equations, that is, we change the speed of real wage adjustment $\left(\Omega_{0}\right)$ towards its targeted level. We perform two separate experiments in which we first reduce the value of $\left(\Omega_{0}\right)$ to 0.25 , and then increase the value of $\left(\Omega_{0}\right)$ to 0.75 . Overall, the results indicate that changes in the speed of wage adjustment lead to different responses in the short run. In particular, a higher speed of adjustment has a stronger effect on relative trade prices, which explains the fluctuation in unemployment and output (see Figures 19 and 20). ${ }^{31}$ In contrast, a low speed of wage adjustment has a small effect on the relative trade prices in the short run, which results in a lower fluctuation (see Figures 21 and 22). These results are not consistent with those of our benchmark model in the short run. However, the response of the model in the long run is quite similar to our benchmark model. ${ }^{32}$

31. As discussed earlier, a union with stronger bargaining power may not be so fast in reinforcing lower wages, in which case this result might not hold. The purpose of these simulations is merely to test the sensitivity of the model.

32. We test the response of the model by changing the key parameters in the consumption function. We find that our results are quite robust to changes in these parameters. 


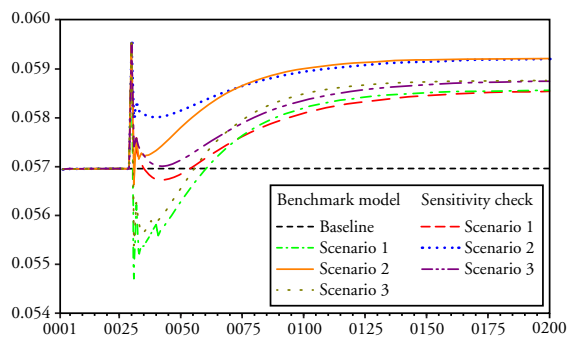

Figure 19 Unemployment rate

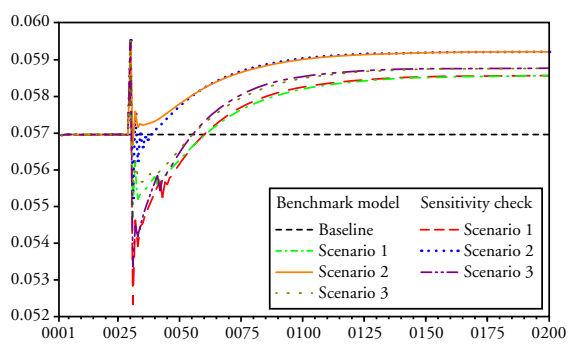

Figure 21 Unemployment rate

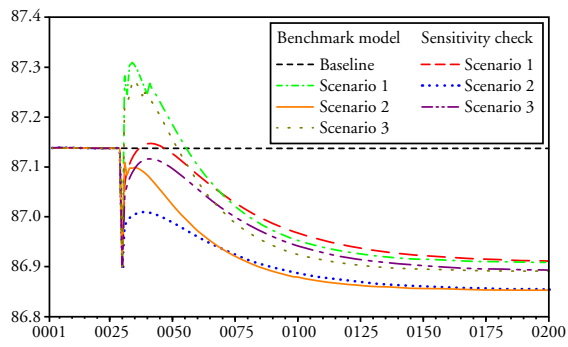

Figure 20 GDP

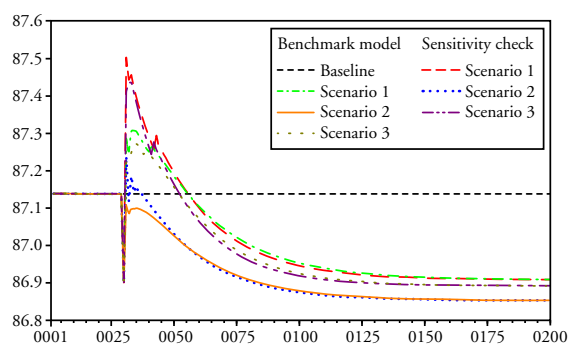

Figure 22 GDP

\subsection{Discussion}

The results from our simulations raise several questions on the economic gains of lower unemployment benefits (UBs) in a small open economy. We show that reductions in UBs lead to a clear tension between a fall in demand and a rise in net exports at a macro level. Our results demonstrate that a lower compensation rate (that is, lower UBs) in a small open economy can compress demand but it may or may not increase the level of competitiveness, depending on the level of real wage rigidity. If wages are rigid, reductions in UBs will negatively affect demand while the level of international price competitiveness will not change to offset the effect of demand compression. In contrast, if wages are flexible, reductions in UBs will result in lower real wages, which will improve the level of competitiveness. However, in this case the gains from increased competitiveness are offset by a much stronger fall in demand due to a decrease in the income of both employed and unemployed households. It is important to highlight that this result may not be valid for profit-led economies, where the gains from increased competitiveness, in response to a fall in wage shares, might be stronger than a fall in domestic demand. However, if resistance to real wage reductions is stronger, then the economy may not benefit from a fall in the compensation rate, and as a result the adverse effects of a fall in domestic demand are likely to be dominant, regardless of the growth regime.

The negative effects of lower unemployment benefits on the income of unemployed households are straightforward, that is, a fall in the compensation rate directly decreases the income of unemployed households. On the other hand, the positive macro effects for example, a rise in net exports or a reduction in the unemployment rate - associated with unemployment benefits are not straightforward. 
Focusing on the labour market, we demonstrated through our simulations that lowering unemployment benefits does not necessarily lead to a decrease in the unemployment rate in the long run. Our results are in sharp contrast to the studies, arguing that a reduction in UBs decreases the unemployment rate. There is a huge controversy regarding the effects of UBs on the unemployment rate. This issue is typically analysed within the framework of utility maximization, where an increase in unemployment benefits has a direct effect on the motivation of the individual to work. A fundamental flaw in the standard models is the exclusive focus on the economic incentive to work while ignoring other social aspects. As described by Van Staveren (2014), the decision whether to apply for a job or not does not depend solely on wages or the loss of income, but a number of social factors. According to Howell/Azizoglu (2011b) and Forges Davanzati (2014), the loss of income is only a small part of the total cost of unemployment: personal costs of unemployment often exceed the economic costs. Larsen (2009) shows that in the majority of studies, non-economic factors increase the incentive to work amongst unemployed individuals. The non-economic factors, for example institutional norms, where unemployed people may be afraid of stigmatization and the need for an identity (workwise) and social belonging, are especially strong in Denmark compared to the rest of the world (ibid.).

The recent developments in the Danish labour market, which reduced the level and duration of UBs, accompanied by a tightening of the eligibility criteria for benefits, are elements of a pro-capital policy as described in Lavoie/Stockhammer (2013). The outcome of such a policy can be very damaging for the Flexicurity system and the economy in the long run. From the point of view of the Danish labour market, the tightening of unemployment benefits leads to a fall in the income security of the workers. This may affect the interest that the unions have in accommodating the flexible nature of the labour market, specifically the flexibility in hiring and firing workers without any compensation. If so, both the flexibility and security aspects of the flexibility model are weakened, which can generate a less dynamic labour market. Another major concern, as pointed out by Lavoie/Stockhammer (2013), is that a pro-capital distribution policy in a wage-led economy leads to dampened growth, unless the effects are offset by other factors such as debt. In this regard, the Danish economy reveals some interesting statistics worth highlighting: Danish households increased their stock of gross debt from 160 per cent of disposable income in 1995 to around 300 per cent in 2010 . At the same time, the Danish trade balance has been in a surplus; net exports have mostly been positive since 1995. Hence, it can be argued that the adverse effects of falling welfare and wage shares on demand have been mitigated by a rise in private debt $-\mathrm{a}$ feature shared by many advanced economies.

For a moment, even if we accept the argument that a change in the compensation rate has an effect on the incentive to work, a natural question that follows is: can an increase in the incentive to work automatically generate employment? Our framework clearly deviates from the traditional assumption of linking employment to the utility maximization problem of workers. In our framework, the level of employment is determined by the level of effective demand in the goods market. The supply of labour is not constrained by the incentive to work, and the compensation rate has no effect on the utility of workers but on the terms of union wage-bargaining. The aggregate effects on unemployment are thus a result of the macroeconomic impact and feedback effects of altering sectoral income and competitiveness, rather than the simplistic aggregation of a microeconomic behavioural assumption. 


\section{CONCLUSION}

The effect of unemployment benefits has been at the centre of both political and economic discussions for the last few decades. According to the political argument, a high level of unemployment benefits affects the incentive to work, and people therefore choose to stay unemployed instead of applying for low-paid jobs. This line of reasoning is backed by a large strand of economic literature, where substitution and income effects are used as an explanation for the choice of whether to work or not. Within this framework, a decrease in the compensation rate leads to an increase in the labour supply, and thereby to an increase in the level of employment.

This paper explored the macroeconomic effects of unemployment benefits within the framework of a simple SFC model for a small open economy. We created three main scenarios: In the first, we reduced the rate of compensation which immediately increased the rate of unemployment due to a fall in domestic demand. In the medium term, however, the unemployment rate fell due to an increase in competitiveness and net exports. This short-run to medium-run response of the model is consistent with the ADAM (2012) model for Denmark. In the long run, however, our story diverges from the short-run results: a reduction in the rate of compensation leads to a permanent increase in the rate of unemployment as demand compression dominates the dynamics of the system. In the second and third scenarios, the prevailing story in the standard economic literature was further challenged. In scenario 2 , when we introduced downward real wage rigidity, a lower compensation rate led to an increase in the rate of unemployment both in the short run and long run. A lower compensation rate in this scenario had a very minor impact on competitiveness, as real wages are resistant to falls. In the third scenario, the elasticity of a change in the rate of employment on targeted wages was lowered, that is, the wage Phillips curve became relatively flat. In this scenario, a reduction in the unemployment benefits showed similar results to the case of scenario 1 . Overall, our results clearly suggest that reduced compensation does not necessarily reduce the unemployment rate. In contrast, we found that a lower compensation rate can increase the rate of unemployment, depending on the magnitude of a fall in demand.

Our conclusion - although in sharp contrast to several studies - finds some support in the literature. The critiques of the prevailing belief, such as Howell/Rehm (2009), have argued that the utility of workers is largely irrelevant for unemployment benefits. Frey/Stutzer (2002) find a positive relationship between employment and happiness. Moreover, it has been argued that the link between unemployment benefits and labour supply is not as obvious as is often stated in economic theory, and the decision to supply labour relies not only on financial motivations but also on social and institutional norms. Another critical point is that an increase in the labour supply does not automatically result in an increase in employment, as is implied by the arguments related to disincentive effects. We show that the level of employment is determined by effective demand in the goods market. This implies that unemployment is a demand-led problem, and not a function of high real wages or high unemployment benefits, as is widely believed in the existing economic literature. The model we present in no way claims to have resolved this issue, but it reveals that the link between unemployment benefits and unemployment rates is more complicated than the type of treatment it has received in the existing literature. The results from our simulations show that a variety of scenarios are possible.

\section{REFERENCES}

Acemoglu, D., Shimer, R. (2000): Productivity gains from unemployment insurance, in: European Economic Review, 44(7), 1195-1224.

ADAM (2003): En modelskitse for arbejdsudbuddet i ADAM, Copenhagen: Danmarks Statistik. 
ADAM (2012): ADAM: A Model of the Danish Economy, Copenhagen: Danmarks Statistik.

Agell, J., Lundborg, P. (2003): Survey evidence on wage rigidity and unemployment: Sweden in the 1990s, in: The Scandinavian Journal of Economics, 105(1), 15-30.

Andersen, T.M., Svarer, M., Vejlin, R.M. (2015): Litteraturreview af effekter af ydelsessystemer, Report to the Commission on UI Benefits, Copenhagen.

Arestis, P., Sawyer, M. (2013): A modern Kaleckian-Keynesian framework for economic theory and policy, in: Harcourt, G.C., Kriesler, P. (eds), The Oxford Handbook of Post-Keynesian Economics, Volume 2: Critiques and Methodology, Oxford: Oxford University Press, 310-325.

Atkinson, A.B., Micklewright, J. (1991): Unemployment compensation and labor market transitions: a critical review, in: Journal of Economic Literature, 29(4), 1679-1727.

Baily, M.N. (1978): Some aspects of optimal unemployment insurance, in: Journal of Public Economics, 10(3), 379-402.

Blanchard, O., Galí, J. (2007): Real wage rigidities and the new Keynesian model, in: Journal of Money, Credit and Banking, 39(s1), 35-65.

Blanchflower, D.G., Oswald, A.J. (2005): The wage curve reloaded, NBER Working Paper No 11338, National Bureau of Economic Research.

Bredgaard, T., Jørgensen, H., Madsen, P.K., Rasmussen, S. (2011): Dansk arbejdsmarkedspolitik, Copenhagen: Jurist-og Økonomforbundet.

Caverzasi, E., Godin, A. (2014): Post-Keynesian stock-flow-consistent modelling: a survey, in: Cambridge Journal of Economics, 39(1), 157-187.

Cevea (2015): Pas på at dagpengenes værdi ikke udhules, URL: https://cevea.dk/debat/29arbejdsmarked/809-pas-paa-dagpengenes-vaerdi-ikke-udhules.

Chetty, R. (2006): A general formula for the optimal level of social insurance, in: Journal of Public Economics, 90(10), 1879-1901.

Chetty, R. (2008): Moral hazard versus liquidity and optimal unemployment insurance, in: Journal of Political Economy, 116(2), 173-234.

Chodorow-Reich, G., Karabarbounis, L. (2016): The limited macroeconomic effects of unemployment benefit extensions, NBER Working Paper No 22163, National Bureau of Economic Research.

Christofides, L.N., Li, D. (2005): Nominal and real wage rigidity in a friction model, in: Economics Letters, 87(2), 235-241.

Danmarks Nationalbank (2013): Danmarks nationalbank kvartals oversigt 2, kvartal, Report, Copenhagen: Rosendahl-Schultz A/S.

Davidson, P. (1998): Post Keynesian employment analysis and the macroeconomics of OECD unemployment, in: The Economic Journal, 108(448), 817-831.

Diamond, P.A. (1982): Wage determination and efficiency in search equilibrium, in: The Review of Economic Studies, 49(2), 217-227.

DØRS (2014): Dansk økonomi, efterår 2014, Report from Danish economic councils, Copenhagen.

Dos Santos, C.H., Zezza, G. (2008): A simplified, benchmark, stock-flow consistent post-Keynesian growth model, in: Metroeconomica, 59(3), 441-478.

Flemming, J.S. (1978): Aspects of optimal unemployment insurance: search, leisure, savings and capital market imperfections, in: Journal of Public Economics, 10(3), 403-425.

Forges Davanzati, G. (2014): Unemployment benefits, the 'added worker effect' and income distribution in a monetary economy, Technical report, Post Keynesian Economics Study Group (PKSG).

Frey, B.S., Stutzer, A. (2002): What can economists learn from happiness research?, in: Journal of Economic Literature, 40(2), 402-435.

Godin, A. (2014): Job guarantee: a structuralist perspective, in: Revue de la régulation: Capitalisme, institutions, pouvoirs, (16), online, URL: http://journals.openedition.org/regulation/10988.

Godley, W., Lavoie, M. (2012): Monetary Economics: An Integrated Approach to Credit, Money, Income, Production and Wealth, 2nd edn, London: Palgrave Macmillan.

Greenwood-Nimmo, M. (2013): Inflation targeting monetary and fiscal policies in a two-country stock-flow-consistent model, in: Cambridge Journal of Economics, 38(4), 839-867. 
Gruber, J. (1997): The consumption smoothing benefits of unemployment insurance, in: The American Economic Review, 87(1), 192-205.

Hall, R.E. (2005): Employment fluctuations with equilibrium wage stickiness, in: The American Economic Review, 95(1), 50-65.

Hein, E., Stockhammer, E. (2011): A post-Keynesian macroeconomic model of inflation, distribution and employment, in: Hein, E., Stockhammer, E. (eds), A Modern Guide to Keynesian Macroeconomics and Economic Policies, Cheltenham, UK and Northampton, MA: Edward Elgar, 112-136.

Holden, S., Wulfsberg, F. (2009): How strong is the macroeconomic case for downward real wage rigidity?, in: Journal of Monetary Economics, 56(4), 605-615.

Hopenhayn, H.A., Nicolini, J.P. (1997): Optimal unemployment insurance, in: Journal of Political Economy, 105(2), 412-438.

Howell, D., Azizoglu, B. (2011a): Unemployment benefits and work incentives: the US labor market in the Great Recession, Political Economy Research Institute, Working Paper No 257, URL: https://www.peri.umass.edu/fileadmin/pdf/working_papers/working_papers_251-300/WP257.pdf.

Howell, D.R., Azizoglu, B.M. (2011b): Unemployment benefits and work incentives: the US labour market in the Great Recession, in: Oxford Review of Economic Policy, 27(2), 221-240.

Howell, D.R., Rehm, M. (2009): Unemployment compensation and high European unemployment: a reassessment with new benefit indicators, in: Oxford Review of Economic Policy, 25(1), 60-93.

Kahneman, D., Tversky, A. (1979): Prospect theory: an analysis of decision under risk, in: Econometrica, 47(2), 363-391.

Katz, L.F., Meyer, B.D. (1990): The impact of the potential duration of unemployment benefits on the duration of unemployment, in: Journal of Public Economics, 41(1), 45-72.

Kekre, R. (2016): Unemployment insurance in macroeconomic stabilization, Working paper, Harvard University, URL: https://scholar.harvard.edu/rkekre/publications/unemployment-insurancemacroeconomic-stabilization- 0 .

Krusell, P., Mukoyama, T., Sahin, A. (2010): Labour-market matching with precautionary savings and aggregate fluctuations, in: The Review of Economic Studies, 77(4), 1477-1507.

Larsen, C.A. (2009): Ledighedsparadokset: information, netvark og selektion på arbejdsmarkedet, Copenhagen: Frydenlund Academics.

Lavoie, M. (2014): Post-Keynesian Economics: New Foundations, Cheltenham, UK and Northampton, MA: Edward Elgar.

Lavoie, M., Daigle, G. (2011): A behavioural finance model of exchange rate expectations within a stock-flow consistent framework, in: Metroeconomica, 62(3), 434-458.

Lavoie, M., Stockhammer, E. (2013): Wage-led growth: concept, theories and policies, in: Lavoie, M., Stockhammer, E. (eds), Wage-Led Growth: An Equitable Strategy for Economic Recovery, London: Springer, 13-39.

Lippman, S.A., McCall, J. (1976): The economics of job search: a survey, in: Economic Inquiry, $14(2), 155-189$.

Madsen, P.K. (2011): Flexicurity i modvind, in: Tidsskrift for arbejdsliv, 13(4), 8-21.

Madsen, P.K. (2015): Dansk flexicurity under pres - både indefra og udefra, Samfundsøkonomen, 2015(1), 5-10.

Mazier, J., Tiou-Tagba Aliti, G. (2012): World imbalances and macroeconomic adjustments: a three-country stock-flow consistent model with fixed or flexible prices, in: Metroeconomica, 63(2), 358-388.

McDonald, I.M., Solow, R.M. (1981): Wage bargaining and employment, in: The American Economic Review, 71(5), 896-908.

Meyer, B.D. (1990): Unemployment insurance and unemployment spells, in: Econometrica, 58(4), 757-782.

Mitman, K., Rabinovich, S. (2015): Optimal unemployment insurance in an equilibrium businesscycle model, in: Journal of Monetary Economics, 71, 99-118.

Mortensen, D.T. (1986): Job search and labor market analysis, in: Handbook of Labor Economics, 2, 849-919. 
Mortensen, D.T., Pissarides, C.A. (1999): New developments in models of search in the labor market, in: Handbook of Labor Economics, 3, 2567-2627.

Nakajima, M. (2012): A quantitative analysis of unemployment benefit extensions, in: Journal of Monetary Economics, 59(7), 686-702.

Narendranathan, W., Stewart, M.B. (1993): How does the benefit effect vary as unemployment spells lengthen?, in: Journal of Applied Econometrics, 8(4), 361-381.

Nijkamp, P., Poot, J. (2005): The last word on the wage curve? A meta-analytic assessment, in: Journal of Economic Surveys, 19(3), 421-450.

Nikiforos, M., Zezza, G. (2017): Stock-flow consistent macroeconomic models: a survey, Levy Economics Institute Working Paper No 891.

Onaran, Ö., Galanis, G. (2013): Is aggregate demand wage-led or profit-led? A global model, in: Lavoie, M., Stockhammer, E. (eds), Wage-Led Growth: An Equitable Strategy for Economic Recovery, London: Springer, 40-70.

Onaran, Ö., Stockhammer, E., Grafl, L. (2011): Financialisation, income distribution and aggregate demand in the USA, in: Cambridge Journal of Economics, 35(4), 637-661.

Rätzel, S. (2009): Revisiting the neoclassical theory of labour supply: disutility of labour, working hours, and happiness, Technical report, FEMM Working Paper No 5.

Rogerson, R., Shimer, R., Wright, R. (2005): Search-theoretic models of the labor market: a survey, in: Journal of Economic Literature, 43(4), 959-988.

Rosholm, M. (2006): Oversigt over litteratur om effekterne af økonomiske incitamenter, Report, København: Beskæftigelsesministeriet.

Scarpetta, S. (1996): Assessing the role of labour market policies and institutional settings on unemployment: a cross-country study, in: OECD Economic Studies, 26(1), 43-98.

Shapiro, C., Stiglitz, J.E. (1984): Equilibrium unemployment as a worker discipline device, in: The American Economic Review, 74(3), 433-444.

Shavell, S., Weiss, L. (1979): The optimal payment of unemployment insurance benefits over time, in: The Journal of Political Economy, 87(6), 1347-1362.

Sørensen, P.B., Whitta-Jacobsen, H.J. (2005): Introducing Advanced Macroeconomics, Maidenhead, UK: McGraw-Hill Education.

Stockhammer, E. (2013): Why have wage shares fallen? An analysis of the determinants of functional income distribution, in: Lavoie, M., Stockhammer, E. (eds), Wage-Led Growth: An Equitable Strategy for Economic Recovery, London: Springer, 40-70.

Van Staveren, I. (2014): Economics After the Crisis: An Introduction to Economics from a Pluralist and Global Perspective, London: Routledge.

\section{APPENDIX 1 BEHAVIOURAL EQUATIONS}

\section{A1.1 Firms}

National income

$$
Y_{t}=C_{t}+I_{t}+G_{t}+X_{t}-M_{t}
$$

Sales

$$
S_{t}=C_{t}+I_{t}+G_{t}+X_{t}
$$

Value of real output

$$
y_{t}=s_{t}-m_{t}
$$

GDP deflator

$$
P_{t}^{y}=Y_{t} / y_{t}
$$


Price of sales

$$
P_{t}^{s}=(1+\phi) \cdot\left(U C_{t}\right)
$$

Unit cost

$$
U C_{t}=\left(W B_{t}+M_{t}\right) / s_{t}
$$

Domestic sales price

$$
P_{t}^{d s}=\frac{S_{t}-X_{t}}{s_{t}-x_{t}}
$$

Real sales

$$
s_{t}=c_{t}+g_{t}+i_{t}+x_{t}
$$

Nominal value of sales

$$
S_{t}=s_{t} \cdot P_{t}^{s}
$$

Real investment

$$
i_{t}=\gamma \cdot\left(k^{T}-k_{t-1}\right)+d a
$$

Targeted stock of capital

$$
k^{T}=\mu . s_{t-1}
$$

Depreciation of capital

$$
d a=\delta . s_{t-1}
$$

Change in stock of capital

$$
\Delta k_{t}=i_{t}-d a
$$

Nominal value of investment

Supply of equity

$$
I_{t}=i_{t} \cdot P_{t}^{d s}
$$

$$
e^{s}=e_{t-1}^{s}+\chi \cdot \Delta k
$$

Profit of the firms

$$
F_{f}=S_{t}-M_{t}-W B_{t}-T_{t}^{f}
$$

Retained profits

$$
F_{r}=I+\Delta H^{f}-\Delta e^{s} \cdot P^{e}
$$

Distributed profits

$$
F_{h}=F_{f}-F_{r}
$$

Demand for domestic currency

$$
H_{t}^{f}=H_{t-1}^{f}+X_{t}-M_{t}
$$


Taxes of the firms

$$
T_{t}^{f}=\theta \cdot\left(Y_{t}-W B_{t}\right)
$$

\section{A1.2 Households}

Household disposable income

$$
Y D_{t}=W B_{t}+r_{t-1} \cdot B_{t-1}^{h}+U B+F_{h}-T_{t}^{h}
$$

Taxes paid by households

$$
T_{t}^{f}=\theta \cdot\left(W B_{t}+r_{t-1}\left(B_{t-1}^{h}\right)+U B\right)
$$

Real disposable income

$$
y d_{t}=\frac{Y D_{t}}{P_{t}^{d s}}-\frac{v_{t-1} \cdot\left(\Delta P^{d s}\right)}{P_{t}^{d s}}
$$

Wealth accumulation

$$
V_{t}=V_{t-1}+Y D_{t}-C_{t}
$$

Real wealth

$$
v_{t}=V_{t} / P_{t}^{d s}
$$

Real consumption

$$
c_{t}=\alpha_{1} \cdot y d_{t}+\alpha_{2} \cdot v_{t-1}
$$

Nominal consumption

$$
C_{t}=c_{t} \cdot P_{t}^{d s}
$$

Demand for bills

Demand for equity

$$
B_{t}^{h}=V_{t} \cdot\left(\lambda_{0}+\lambda_{1} \cdot\left(r_{t}\right)-\lambda_{2} \cdot\left(Y D_{t} / V_{t}\right)\right)
$$

$$
e^{d}=e^{s}
$$

Demand for domestic currency

$$
H_{t}^{h}=V_{t}-B_{t}^{h}-e^{d} \cdot P^{e}
$$

\section{A1.3 Government}

Tax revenue

$$
T_{t}=T_{t}^{f}+T_{t}^{h}
$$

Supply of government bills

$$
B_{S_{t}}=B_{S_{t-1}}+G_{t}+U B_{t}+r_{t-1} \cdot B_{S_{t-1}}-T_{t}-r_{t-1} \cdot B_{t-1}^{c b}
$$




\section{A1.4 Central bank}

Government bills held by the Central bank

$$
B_{t}^{c b}=B_{S_{t}}-B_{t}^{h}
$$

Demand for foreign currency, that is, the foreign currency reserves generated by the surplus on trade

$$
F x=F x_{t-1}+\left(\frac{\Delta H_{t}^{f}}{X R}\right) \quad \text { where }\left(X R=\frac{\Delta H_{t}^{f}}{\Delta F x_{t}}=1\right) \text { is implicit in the model }
$$

Supply of currency by the central bank

$$
H_{S_{t}}=H_{S_{t-1}}+B_{t}^{c b}-B_{t-1}^{c b}+H_{t}^{f}-H_{t-1}^{f}
$$

\section{A1.5 Labour market}

Employment

$$
N_{t}=y_{t} / A_{t}
$$

Wage bill

$$
W B_{t}=W_{t} \cdot N_{t}
$$

Unemployment

$$
U N_{t}=L f_{t}-N_{t}
$$

Unemployment benefits

$$
U B_{t}=\xi . W_{t} \cdot U N_{t}
$$

Employment rate

$$
E R_{t}=\frac{N_{t}}{L f_{t}}
$$

Unemployment rate

$$
U R_{t}=1-\frac{N_{t}}{L f_{t}}
$$

Labour force

$$
L f=a c t . P o p,
$$

where $P o p$ is the total population

Labour participation rate

$$
\ln (a c t)=\Phi_{0}+\Phi_{1} \cdot \ln \left(\frac{W_{t}}{P_{t}^{d s}}\right)+\Phi_{2} \cdot \ln \left(E R_{t-1}\right)
$$

Nominal wage rate

$$
W_{t}=W_{t-1}+\Omega_{0} \cdot\left(w_{t-1}^{*}-w_{t-1}\right)
$$


Real wage

$$
w_{t}=\frac{W_{t}}{P_{t}^{d s}}
$$

Targeted wage rate

$$
\ln w^{*}=\beta_{0}+\beta_{1} \cdot \ln \left(A_{t}\right)+\beta_{2} \cdot \ln (\xi)+\beta_{3} \cdot \ln \left(E R_{t-1}\right)
$$

\section{A1.6 Balance of payments and trade}

Import prices

$$
\ln \left(P_{t}^{m}\right)=v_{m_{0}}+v_{m_{1}} \cdot \ln \left(P_{t}^{y^{*}}\right)+\left(1-v_{m_{1}}\right) \cdot \ln \left(P_{t}^{y}\right)+v_{m_{1}} \cdot \ln (X R)
$$

Export prices

$$
\ln \left(P_{t}^{x}\right)=\nu_{x_{0}}+v_{x_{1}} \cdot \ln \left(P_{t}^{y^{*}}\right)+\left(1-v_{x_{1}}\right) \cdot \ln \left(P_{t}^{y}\right)+v_{x_{1}} \cdot \ln (X R)
$$

where $X R$ is the nominal exchange rate, which is fixed to 1 in our model.

Real imports

$$
\ln \left(m_{t}\right)=\mu_{0}-\mu_{1} \cdot \ln \left(\frac{P_{t-1}^{m}}{P_{t-1}^{y}}\right)+\mu_{2} \cdot \ln \left(y_{t}\right)
$$

Real exports

$$
\ln \left(x_{t}\right)=\epsilon_{0}-\epsilon_{1} \cdot \ln \left(\frac{P_{t-1}^{x}}{P_{t-1}^{y^{*}}}\right)+\epsilon_{2} \cdot \ln \left(y_{t}^{*}\right)
$$

Nominal imports

$$
M_{t}=m_{t} \cdot P^{m}
$$

Nominal exports

Current account balance

$$
X_{t}=x_{t} \cdot P^{x}
$$

$$
C A B_{t}=X_{t}-M_{t}
$$

Financial account balance

$$
F A B_{t}=-\Delta F x \cdot X R
$$

\section{A1.7 Asset market equilibrium}

Total demand and supply of bills

$$
\underbrace{B_{S_{t}}}_{\text {Bills issued }}=\underbrace{B_{t}^{h}+B_{t}^{c b}}_{\text {Bills demanded }}
$$

Total demand and supply for domestic currency

$$
\underbrace{H_{S_{t}}}_{\text {Currency issued }}=\underbrace{H_{t}^{h}+H_{t}^{f}}_{\text {Currency demanded }}
$$


Total demand and supply for foreign currency

$$
\underbrace{F x_{t}^{*}}_{\text {Fx issued }}=\underbrace{F x_{t}}_{\text {Fx demanded }}
$$

Parameter and exogenous variables:

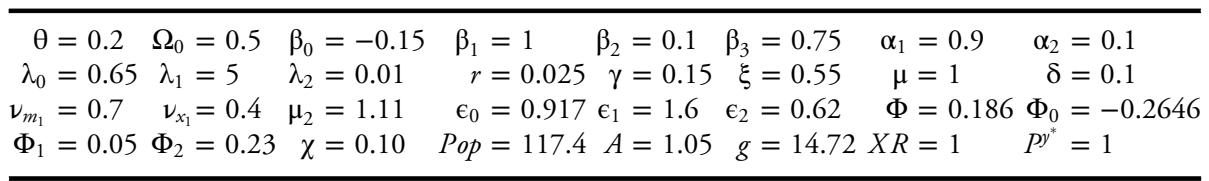

